\title{
MUTU ORGANOLEPTIK DAN TOTAL BAKTERI ASAM LAKTAT YOGURT SARI JAGUNG DENGAN PENAMBAHAN SUSU SKIM DAN KARAGENAN
}

\author{
Sensory Evaluation and Total Lactic Acid Bacteria Quality of Corn Concentrate Yogurt \\ with Skim milk and Carrageenan \\ Premy Puspitawati Rahayu ${ }^{1}$ Ria Dewi Andriani ${ }^{1)}$ \\ 1) Teknologi Hasil Ternak, Fakultas Peternakan Universitas Brawijaya, Jl. Veteran. Malang, Jawa Timur. Indonesia. 65145 \\ Email: premypuspita@ub.ac.id
}

Diterima 8 Februari 2018; diterima pasca revisi 21 Maret 2018

Layak diterbitkan 28 Maret 2018

\begin{abstract}
The objective of this research was to analyze sensory evaluation quality and total lactic acid bacteria of corn yogurt added with skim milk and carrageenan. This research used experimental laboratory method with completely randomized design and four replications. The treatment used were skim milk with concentration $(2.5 ; 3 ; 3.5 \% \mathrm{~b} / \mathrm{v})$ dan carrageenan $(0.5 ; 0.75 ; 1 \% \mathrm{~b} / \mathrm{v})$. The result showed that the treatment gave significant different effect $(p<0,05)$ on sensory evaluation quality from texture aspect; the addition of various concentrations of skim milk, and carrageenan concentrations, and the interaction did not give a different effect $(p>0.05)$ on the total lactic acid bacteria, organoleptic (aroma and color). The addition of various of skim milk, and carrageenan concentrations gave total of total lactic acid bacteria, organoleptic (color, aroma and texture) was $2.83 \times 10^{8}-4.4 \times$ $10^{8} \mathrm{CFU} / \mathrm{ml}$; white to yellowness; acidness to acid; and thickness to thick. The best treatment of this research is the addition of skim 5\% and carrageenan $0.75 \%$ with total lactic acid bacteria $4.4 \times 10^{8}$, the aroma is acidness, the color is yellowness, the texture is thickness. It could be concluded that the addition of skim milk and carrageenan in corn yogurt production can be accepted by consumers and increase the activity of lactic acid bacteria
\end{abstract}

Keywords: Yogurt; corn concentrate;skim; carrageenan

\begin{abstract}
ABSTRAK
Penelitian ini bertujuan untuk menganalisis mutu organoleptik dan total bakteri asam laktat yogurt sari jagung yang ditambahkan dengan susu skim dan karagenan. Penelitian menggunakan metode percobaan faktorial dengan rancangan acak lengkap dan empat kali ulangan. Penelitian menggunakan perlakuan konsentrasi susu skim $(2,5 ; 3 ; 3,5 \% \mathrm{~b} / \mathrm{v})$ dan karagenan $(0,5 ; 0,75 ; 1 \% \mathrm{~b} / \mathrm{v})$. Hasil penelitian penambahan susu skim dan karagenan pada yogurt sari jagung menunjukkan pengaruh yang berbeda nyata $(P<0,05)$ terhadap mutu organoleptik dari segi tekstur; sedangkan penambahan berbagai konsentrasi susu skim, penambahan berbagai konsentrasi karagenan, dan interaksi antara penambahan berbagai konsentrasi susu skim dengan penambahan berbagai konsentrasi karagenan tidak memberikan pengaruh yang berbeda $(p>0,05)$ terhadap total bakteri asam laktat, organoleptik dilihat dari segi aroma dan warna. Dari hasil penelitian rata-rata total

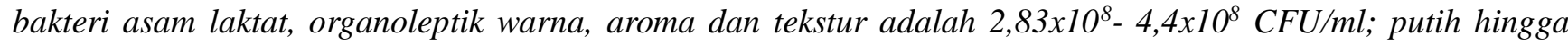
putih kekuningan; agak asam hingga asam; dan agak kental hingga kental.Perlakuan terbaik dari penelitian yaitu penambahan skim 5\% dan karagenan 0,75\% dengan total bakteri asam laktat 4,40 $\times 10^{8}$, aroma agak kurang asam, warna agak kurang putih, tekstur agak kurang kental. Kesimpulan hasil penelitian bahwa penambahan susu skim dan karagenan pada yogurt sari jagung menghasilkan produk yang dapat diterima oleh konsumen dan meningkatkan aktivitas bakteri asam laktat
\end{abstract}

Kata Kunci: Yogurt; sari jagung; skim; karagenan 


\section{PENDAHULUAN}

Yogurt merupakan salah satu produk olahan hasil ternak yang memiliki manfaat bagi kesehatan. Proses pembuatan yogurt biasanya menggunakan susu secara utuh (whole milk) yang memberikan aroma dan rasa yang lebih menarik. Namun yang perlu diketahui, susu mengandung asam lemakjenuh yang cukup tinggi yang dapat meningkatkan kadar kolesterol tubuh, meningkatkan tekanan darah dan penyempitan pembuluh darah pada otak (Mazahreh, and Ershidat, 2009). Upaya yang dapat dilakukan untuk mengurangi kekhawatiran dalam mengkonsumsi yogurt dan menurunkan resiko di atas adalah dengan menggunakan susu skim yang rendah lemak.

Beberapa inovasi dan upaya yang dilakukan untuk menurunkan kandungan lemak dan meningkatkan sifat fungsional yogurt adalah dengan menambahkan bahan yang kaya akan serat atau menggunakan sari sayuran diantaranya wortel, inulin, labu kuning, jagung manis dan lain-lain. Labu kuning yang kaya akan betakaroten dapat digunakan dalam pembuatan yogurt dengan lama penyimpanan maksimal 10 hari, dan diperoleh sensorik terbaik pada penyimpanan hari ke 6 (Yulianawati, 2012).

Pemanfaatan jagung manis dalam pembuatan yogurt memiliki potensi yang cukup tinggi mengingat jagung mengandung karbohidrat dan gula pereduksi yang cukup tinggi serta kaya akan serat. Kandungan gula pereduksi yang cukup tinggi berkisar 5-6\% dan kadar pati $10-11 \%$ dapat digunakan sebagai media tumbuh bagi bakteri asam laktat, vitamin B kompleks, sebagai sumber antioksidan yang

*Corresponding author:

Premy Puspita Rahayu

Email : premypuspita@ub.ac.id

Teknologi Hasil Ternak, Fakultas Peternakan Universitas Brawijaya, Jl. Veteran. Malang, Jawa Timur. Indonesia. 65145 baik bagi kesehatan, sehingga dapat digunakan dalam pembuatan yogurt.

Faktor yang mempengaruhi kualitas yogurt antara lain substrat, jenis starter, konsentrasi starter, suhu dan waktu inkubasi. Produk fermentasi yang tidak berbahan dasar susu mudah sekali mengalami sineresis, oleh karena itu dibutuhkan bahan yang menghasilkan yogurt dengan tekstur yang stabil. Penelitian ini menggunakan yogurt dengan penambahan skim dan karagenan. Skim dan sari jagung manis berperan dalam pertumbuhan bakteri asam laktat karena kandungan laktosa yang ada dalam skim merupakan nutrisi bakteri asam laktat, namun diperlukan pengujian total bakteri asam laktat pada yogurt tersebut. Karagenan berperan sebagai penstabil dalam mempertahankan sifat fisik yogurt. Selain itu pengujian organoleptik diperlukan untuk mengetahui daya terima konsumen terhadap produk yogurt sari jagung dengan penambahan skim dan karagenan.

Mutu organoleptik dan total bakteri asam laktat merupakan salah satu faktor yang perlu dievaluasi untuk menilai produk tersebut memiliki kualitas yang baik secara mikrobiologi dan dapat diterima oleh konsumen berdasarkan pengujian organoleptik. Berdasarkan hal tersebut, perlu dilakukan penelitian untuk mengetahui total bakteri asam laktat dan mutu organoleptik yogurt sari jagung dengan penambahan skim dan karagenan. Penggunaan sari jagung manis pada pembuatan yogurt dengan penambahan susu skim dan karagenan merupakan pengembangan yogurt menjadi produk fungsional yang dapat diterima oleh masyarakat.

How to cite:

Rahayu, P. P. \& Andriani, R.D. (2018). Mutu Organoleptik dan Total Bakteri Asam Laktat Yogurt Sari Jagung dengan Penambahan Susu Skim dan Karagenan. Jurnal Ilmu dan Teknologi Hasil Ternak, $13(1), 38-45$ 


\section{MATERI DAN METODE}

\section{Materi}

Materi dalam penelitian meliputi sari jagung manis, susu skim, air mineral, karagenan, starter Lactobacillus bulgaricus dan Streptococcus thermophillus, sukrosa, aquades, MRS agar, pepton, dan alkohol 70\%. Alat yang digunakan meliputi tabung reaksi, erlenmeyer, pipet tetes, cawan petri, inkubator, mikropipet dan kuisioner uji organoleptik.

\section{Metode Penelitian}

Penelitian menggunakan metode percobaan faktorial dengan rancangan acak lengkap dan empat kali ulangan. Perlakuan pada konsentrasi susu skim $(2,5 \% ; 3 \% ; 3,5 \%)$ (b/v) dan konsentrasi karagenan $(0,5 \% ; 0,75 \%$; $1,0 \%)(\mathrm{b} / \mathrm{v})$. Terdiri dari 3 tahapan dalam penelitian ini meliputi persiapan bahan dan kultur, pembuatan sari jagung dan pembuatan yogurt.

\section{Pembuatan Sari Jagung}

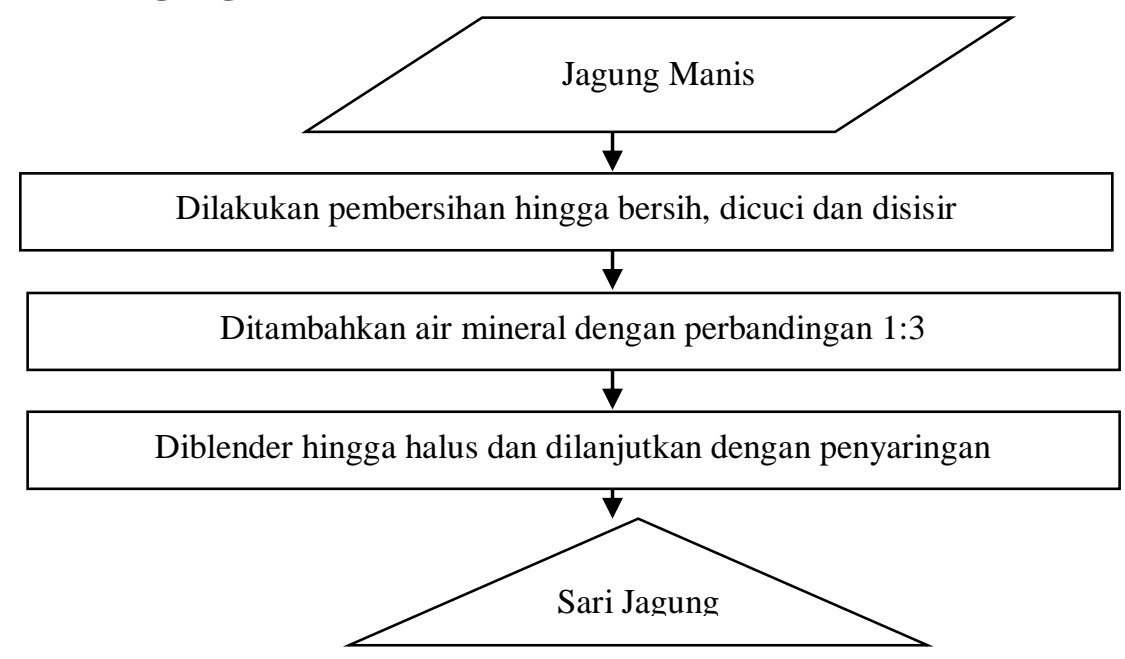

Gambar 1. Prosedur Pembuatan Sari Jagung dan Gambar 2. Prosedur Persiapan Kultur

\section{Persiapan Kultur}
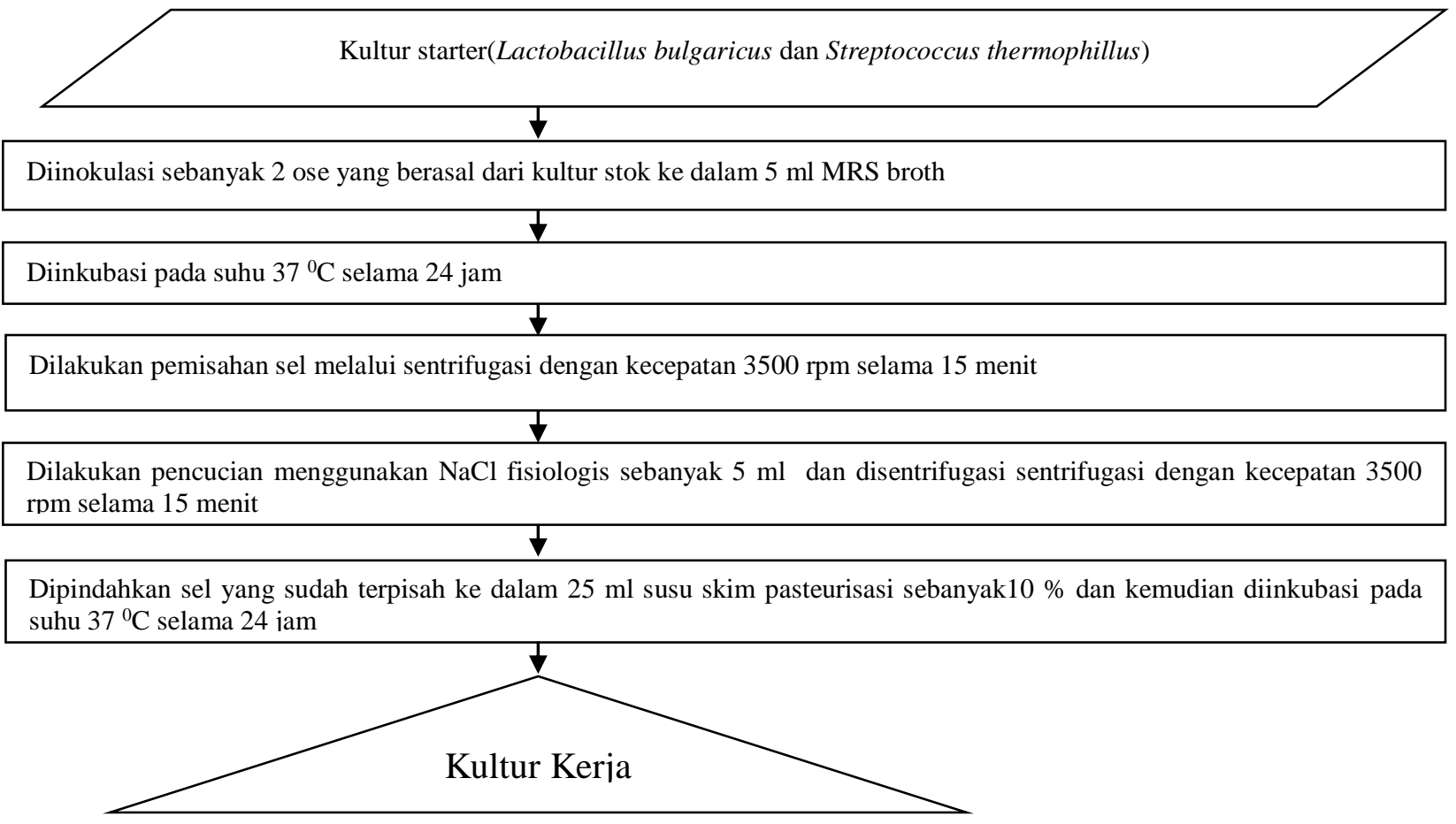


\section{Pembuatan Yogurt}

Pembuatan sari jagung manis sebagai bahan baku dari yogurt,dan dilakukan penambahan susu skim $(2,5 ; 3 ; 3,5 \% \mathrm{~b} / \mathrm{v})$ dan karagenan $(0,5 ; 0,75 ; 1 \%$ b/v) yang kemudian dipasteurisasi hingga mencapai suhu $72{ }^{0} \mathrm{C}$ selama 15 menit. Selanjutnya dilakukan inokulasi kultur starter sebanyak 3\% pada suhu ruang $\pm 40{ }^{\circ} \mathrm{C}$, dan diinkubasi pada suhu ruang selama 18 jam. Selanjutnya dilakukan analisa total bakteri asam laktat, organoleptik warna, aroma dan tekstur.

\section{Metode Pengujian Total Bakteri Asam Laktat}

Total BAL ditentukan menggunakan metode hitung cawan (Total Plate Count) menggunakan media tumbuh Man Rogosa and Sharpe (MRS). MRS agar dibuat dengan cara melarutkan 65,13 g ke dalam $1000 \mathrm{ml}$ aquades, dan disterilkan menggunakan autoclave pada suhu $121^{\circ} \mathrm{C}$ selama 15 menit. Pengujiannya dimulai dengan mengencerkan yogurt dalam aquades steril menggunakan perbandingan 1:9, pengenceran dilakukan mulai dari $10^{1}-10^{8}$. Pencawanan dilakukan dengan mengambil $1 \mathrm{ml}$ sampel yag telah diencerkan ke dalam cawan, dilakukan pada pengenceran $10^{6}-10^{8}$. Kemudian ditambahkan MRS agar setengah padat $\pm 10 \mathrm{ml}$, lalu cawan dihomogenkan dengan cara digerakkan membentuk angka 8 . Ditunggu hingga padat dan diinkubasi dengan posisi terbalik menggunakan suhu $37^{\circ} \mathrm{C}$ selama 48 jam(Fardiaz, 1993).

\section{Metode Pengujian Mutu Organoleptik}

Sampel dilakukan analisa mutu organoleptik meliputi warna, aroma dan tekstur dengan 15 panelis yang terdiri dari mahasiswa dan non-staf pengajar Fakultas Peternakan Universitas Brawijaya. Menggunakan 5 skala hedonik mulai dari yang sangat baik (skor $=5$ ) hingga sangat kurang (skor $=0)($ Obi et al., 2010).

\section{Analisis Data}

Data total bakteri asam laktat, organoleptik dilihat dari segi aroma, tekstur dan warna dianalisis menggunakan analisis ragam (ANOVA) dan dilanjutkan dengan uji beda nyata jujur.

\section{HASIL DAN PEMBAHASAN}

\section{Total Bakteri Asam Laktat}

Penentuan total bakteri asam laktat merupakan salah satu yang penting yang perlu dilakukan untuk memastikan bahwa produk yogurt ini merupakan termasuk produk fungsional. Syarat total bakteri asam laktat sebesar $10^{6}-10^{8} \mathrm{cfu} / \mathrm{ml}$ sesuai (FAO/WHO, 2002). Guna menciptakan produk pangan fungsional yang baik bagi kesehatan, produk tersebut harus mengandung starter hidup sebesar $10^{7}-10^{9} \mathrm{cfu} / \mathrm{ml}$ (Oliveira et al., 2008). Total bakteri asam laktat pada yogurt dengan penambahan susu skim dan karagenan dengan konsentrasi berbeda dapat dilihat pada Tabel 1 .

Tabel 1. Total Bakteri Asam Laktat sari jagung dengan penambahan susu skim dan karagenan

\begin{tabular}{ccccc}
\hline $\begin{array}{c}\text { Susu skim } \\
(\%)\end{array}$ & 0,25 & Karagenan $(\%)$ & $\begin{array}{c}\text { Rata-rata } \\
(\mathrm{CFU} / \mathrm{ml})\end{array}$ \\
\cline { 2 - 4 } & $2,83 \times 10^{8}$ & $3,56 \times 10^{8}$ & 0,75 & $3,83 \times 10^{8}$ \\
4 & $3,47 \times 10^{8}$ & $3,86 \times 10^{8}$ & $4,06 \times 10^{8}$ & $3,80 \times 10^{8}$ \\
5 & $3,53 \times 10^{8}$ & $4,26 \times 10^{8}$ & $4,40 \times 10^{8}$ & $4.06 \times 10^{8}$ \\
\hline Rata-rata (CFU/ml) & $3,28 \times 10^{8}$ & $3,89 \times 10^{8}$ & $4,09 \times 10^{8}$ & \\
\hline
\end{tabular}

Berdasarkan hasil analisis ragam menunjukkan bahwa tidak terdapat perbedaan yang nyata antara perlakuan konsentrasi susu skim, konsentrasi karagenan, interaksi antara penambahan berbagai konsentrasi susu skim dengan penambahan berbagai konsentrasi karagenan $(\mathrm{p}>0,05)$ terhadap total bakteri asam laktat dalam yogurt sari jagung. Rata-rata total bakteri asam laktat berkisar antara 2,83 x $10^{8}$ hingga 4,4 x $10^{8} \mathrm{CFU} / \mathrm{ml}$. Nilai tersebut sesuai SNI (2981:2009), bahwa yogurt mengandung bakteri asam laktat/probiotik minimal 
$10^{7} \mathrm{cfu} / \mathrm{ml}$. Data beberapa penelitian menampilkan total bakteri asam laktat sebesar $1,0 \times 10^{6}$ sampai $5,6 \times 10^{7} \mathrm{CFU} / \mathrm{ml}$ (Khalil dan Anwar, 2016).

Berdasarkan analisa statistik data total bakteri asam laktat tidak terdapat perbedaan yang nyata, namun dilihat dari data diatas terlihat bahwa semakin tinggi penggunaan susu skim maka nilai total BAL yang dihasilkan pun juga semakin meningkat. Hal tersebut karena skim merupakan substrat yang digunakan sebagai media tumbuh bakteri. Bakteri yang tumbuh dalam pangan bersifat heterotropik, memerlukan zat organik berupa karbohidrat, protein, lemak dan komponen lain sumber karbon dan energi sebagai media tumbuh. Substrat yogurt sari jagung berasal dari sari jagung, skim, dan karagenan, skim mengandung laktosa yang merupakan sumber energi yang selanjutnya dipecah dahulu menjadi glukosa, kemudian glukosa dioksidasi menjadi asam piruvat, asam laktat, $\mathrm{CO}_{2}$, dan etanol. Penggunaan skim dan karagenan dapat meningkatkan nilai total bakteri asam laktat, hal tersebut karena skim mengandung protein, merupakan substrat yang berperan sebagai sumber energi sehingga menstimulasi pertumbuhan bakteri asam laktat. Karagenan merupakan jenis polisakarida, berperan sebagai substrat yang menghasilkan energi untuk pertumbuhan bakteri asam laktat. Semakin tinggi penambahan skim dan karagenan maka total BAL akan semakin tinggi.

Yogurt merupakan produk fermentasi yang populer di Indonesia, tujuan awal memproduksi yogurt untuk memperpanjang umur simpan susu segar melalui fermentasi. Sebagian besar yogurt komersial berbahan dasar susu sapi, karena rasa, aroma asli, dan nilai nutrisinya yang sangat bermanfaat bagi kesehatan. Kesadaran konsumen akan pentingnya kesehatan, sehingga ada pengembangan produk yogurt dengan pemanfaatan probiotik yang berperan penting dalam sistem pencernaan manusia (Ataiejafari et al., 2009), dan dapat dimanfaatkan sebagai terapi (Lourens-Hattingh dan Viljoen 2001) misalnya untuk menurunkan kolesterol (Agerholm-Larsen, 2000), mencegah gastrointestinal, meningkatkan kesediaan mineral, dan memberikan efek imunologis (Meydani dan Ha 2000; Anukam et al., 2008).

\section{Organoleptik Warna}

Analisa organoleptik warna pada yogurt merupakan salah satu faktor yang perlu diperhatikan karena dapat berpengaruh terhadap tampilan produk dan penerimaan konsumen. Organoleptik warna pada yogurt dengan penambahan susu skim dan karagenan dengan konsentrasi berbeda dapat dilihat pada Tabel 2.

Tabel 2. Rata-rata organoleptikwarna yogurt sari jagung dengan penambahan susu skim dan karagenan

\begin{tabular}{ccccc}
\hline $\begin{array}{c}\text { Susu skim } \\
(\%)\end{array}$ & \multicolumn{3}{c}{ Karagenan $(\%)$} & Rata-rata \\
\cline { 2 - 4 } & 0,25 & 0,50 & 0,75 & 2,24 \\
4 & 2,33 & 2,27 & 2,13 & 2,13 \\
5 & 2,20 & 2,13 & 2,07 & 2,07 \\
\hline Rata-rata & 2,07 & 2,07 & 2,07 & \\
\hline
\end{tabular}

Hasil analisa statistik menunjukkan bahwa tidak terdapat perbedaan yang nyata antara perlakuan konsentrasi susu skim, konsentrasi karagenan, interaksi antara penambahan berbagai konsentrasi susu skim dengan penambahan berbagai konsentrasi karagenan $(p>0,05)$ terhadap mutu organoleptik warna. Rata-rata nilai mutu organoleptik terhadap warna berkisar antara 2,07 hingga 2,24 yang berarti memiliki warna putih hingga putih kekuningan. Warna kekuningan disebabkan karena adanya karoten yang terkanduung dalam jagung dan susu (Omueti dan Ajomale, 2005). Semakin tinggi penambahan susu skim dan karagenan memberikan nilai yang semakin rendah 
terhadap organoleptik warna pada yogurt sari jagung dengan penambahan skim dan karagenan. Perubahan warna jagung dari putih kekuningan hingga putih disebabkan karena penambahan skim dan karagenan. Susu skim berwarna putih, hal ini menyebabkan penambahan konsentrasi susu skim dapat mengakibatkan warna yogurt makin menuju ke warna putih. Warna memiliki peran yang penting dalam penilaian konsumen.
Warna dapat digunakan untuk mengidentifikasi kualitas dari suatu produk.

\section{Organoleptik Aroma}

Analisa organoleptik aroma yogurt dapat menentukan kelayakan produk dan penerimaan konsumen. Rata-rata skor organoleptik aroma pada yogurt dengan penambahan susu skim dan karagenan dengan konsentrasi berbeda dapat dilihat pada Tabel 3 .

Tabel 3. Rata-rata skor organoleptik aromayogurt sari jagung dengan penambahan susu skim dan karagenan

\begin{tabular}{ccccc}
\hline \multirow{2}{*}{$\begin{array}{c}\text { Susu skim } \\
(\%)\end{array}$} & \multicolumn{3}{c}{ Karagenan $(\%)$} & Rata-rata \\
\cline { 2 - 4 } & 0,25 & 0,50 & 0,75 & 2,27 \\
4 & 2,40 & 2,20 & 2,20 & 2,22 \\
5 & 2,33 & 2,13 & 2,20 & 2,11 \\
\hline Rata-rata & 2,07 & 2,13 & 2,13 & \\
\hline
\end{tabular}

Berdasarkan hasil statistik menunjukkan bahwa tidak terdapat perbedaan yang nyata antara perlakuan konsentrasi susu skim, konsentrasi karagenan, interaksi antara penambahan berbagai konsentrasi susu skim dengan penambahan berbagai konsentrasi karagenan $(\mathrm{P}>0,05)$ terhadap organoleptik aroma. Rata-rata nilai aroma berkisar antara 2,11 hingga 2,27 yang berarti memiliki aroma agak asam hingga asam. Semakin tinggi penambahan susu skim dan karagenan memberikan nilai yang semakin rendah terhadap organoleptik aroma pada yogurt sari jagung dengan penambahan skim dan karagenan. Semakin tinggi penambahan skim dan karagenan aroma yogurt sari jagung semakin asam dan aroma jagung manis semakin berkurang. Karakteristik warna dan tekstur produk merupakan faktor penting yang mempengaruhi kualitas produk, namun aroma dan rasa produk merupakan indikator yang paling penting terhadap penerimaan konsumen (Bodyfelt et al., 1988).

\section{OrganoleptikTekstur}

Analisa organoleptik tekstur yogurt merupakan salah satu indikator yang perlu diketahui untuk menentukan kualitas sensorik dan penerimaan konsumen. Rata-rata organoleptik tekstur pada yogurt dengan penambahan susu skim dan karagenan dengan konsentrasi berbeda dapat dilihat pada Tabel 3 .

Tabel 4. Rata-rata skor tekstur yogurt sari jagung dengan penambahan susu skim dan karagenan

\begin{tabular}{ccccc}
\hline \multirow{2}{*}{$\begin{array}{c}\text { Susu skim } \\
(\%)\end{array}$} & \multicolumn{3}{c}{ Karagenan $(\%)$} & Rata-rata \\
\cline { 2 - 4 } & 0,25 & 0,50 & 0,75 & $2,60^{\mathrm{c}}$ \\
4 & 2,60 & 2,60 & 2,60 & $2,33^{\mathrm{b}}$ \\
5 & 2,40 & 2,33 & 2,27 & $2,12^{\mathrm{a}}$ \\
\hline Rata-rata & 2,10 & 2,13 & 2,13 & \\
\hline
\end{tabular}

a, b, c Notasi berbeda dalam kolom yang sama menunjukkan adanya perbedaan yang nyata pada masing-masing perlakuan $(\mathrm{p}<0,05)$. 
Berdasarkan analisis secara statistik, terdapat perbedaan yang nyata antara perlakuan konsentrasi susu skim dengan perlakuan konsentrasi karagenan $(\mathrm{p}<0,05)$, dan tidak terdapat interaksi antara penambahan berbagai konsentrasi susu skim dengan penambahan berbagai konsentrasi karagenan $(p>0,05)$ terhadap organoleptik tekstur. Rata-rata nilai organoleptik tekstur berkisar antara 2,12 hingga 2,60 yang berarti memiliki tekstur agak kental hingga kental. Semakin tinggi penambahan susu skim dan karagenan memberikan nilai yang semakin rendah terhadap organoleptik warna pada yogurt sari jagung dengan penambahan skim dan karagenan. Penambahan skim dan karagenan dapat meningkatkan kekentalan dilihat dari tekstur organoleptik. Hal tersebut disebabkan karena penggunaan susu skim meningkatkan proses koagulasi protein selama proses fermentasi sehingga yogurt menghasilkan tekstur yang lebih kental. Perubahan tekstur pada protein susu biasanya juga disebabkan karena adanya interaksi antara protein dengan bahan tertentu, disini skim berinteraksi dengan karagenan dan sari jagung yang menyebabkan tekstur kental. Hal tersebut sesuai dengan Rahayu et al. (2015) yang menjelaskan bahwa adanya interaksi antara protein susu dengan senyawa lainnya akan mempengaruhi sifat fungsional protein tersebut. Semakin kental tekstur yogurt dapat disebabkan bahan memiliki daya ikat yang lebih baik. Bahan mempunyai kemampuan meembentuk matriks yang dapat menangkap air sehingga menyebabkan viskositas semakin kental (Pangestu et al., 2017).

\section{KESIMPULAN}

Kesimpulan hasil penelitian bahwa penambahan susu skim dan karagenan pada yogurt sari jagung menghasilkan produk yang dapat diterima oleh konsumen dan meningkatkan aktivitas bakteri asam laktat.

\section{DAFTAR PUSTAKA}

Agerholm-Larsen, L., Raben, A., Haulrik, N., Hansen, A., Manders, M., \& Astrup, A. (2000). Effect of 8 week intake of probiotic milk products on risk factors for cardiovascular diseases. European Journal of Clinical Nutrition, 54(4), 288297.

Anukam, K. C., Osazuwa, E. O., Osadolor, H. B., Bruce, A. W., \& Reid, G. (2008). Yogurt containing probiotic lactobacillus rhamnosus gr-1 \& 1 . reuteri rc-14 helps resolve moderate diarrhea \& increases CD4 count in HIV/AIDS patients. Journal of Clinical Gastroenterology, PAP(3), 239-43. https://doi.org/10.1097/MCG.0b013e31802c7465

Bodyfelt, F. W., Clark, S., \& Costello, M. (2009). The sensory evaluation of dairy products. Springer.New York.

Fadela, C., Abderrahim, C., \& Ahmed, B. (2009). Sensorial \& physico-chemical characteristics of yogurt manufactured with ewe's \& skim milk. World Journal of Dairy \& Food Sciences, 4(2), 136140.

Fardiaz, S. (1993). Analisis mikrobiologi pangan / Srikandi Fardiaz. Jakarta: Raja Grafindo Persada.

Fox, P. F., Uniacke-Lowe, T., McSweeney, P. L. H., \& O’Mahony, J. A. (2015). Dairy chemistry \& biochemistry. Cham: Springer International Publishing. https://doi.org/10.1007/978-3-319-14892-2

Khalil, M. I., \& Anwar, N. (2016). Isolation, identification \& characterization of lactic acid bacteria from milk \& yogurts. Journal of Food \& Dairy Technology, 4(3), 17-26. 
Lourens-Hattingh, A., \& Viljoen, B. C. (2001). Yogurt as probiotic carrier food. International Dairy Journal, 11(1), 1-17.

Mazahreh, A. S., \& Ershidat, O. T. M. (2009). The benefits of lactic acid bacteria in yogurt on the gastrointestinal function \& health. Pakistan Journal of Nutrition, $8(9)$, 1404-1410. https://doi.org/10.3923/pjn.2009.1404.1410

Meydani, S. N., \& Ha, W. K. (2000). Immunologic effects of yogurt. The American Journal of Clinical Nutrition, 71(4), 861-72.

Obi, T. E., Henshaw, F. O., \& Atanda, O.O.. (2010). Quality cultures \& their physiochemical analysis during evaluation of plain-stirred probiotic yogurt storage. Afr. J. Biotech, 9: 29132917.

Omueti, O., \& Ajomale, K. (2005). Chemical \& sensory attributes of soy-corn milk types. African Journal of Biotechnology, 4(6), 847-851.
Pangestu, R. F., Legowo, A. M., Al-Baarri, A. N., \& Pranomo, Y. B. (2017). Aktivitas antioksidan, $\mathrm{pH}$, viskositas, viabilitas bakteri asam laktat (bal) pada yogurt powder daun kopi dengan jumlah karagenan yang berbeda. Jurnal Aplikasi Teknologi Pangan, 6(2), 78-84. https://doi.org/10.17728/jatp.185

Rahayu, P.P., Radiati, L.E., Purwadi, \& Manab, A. (2015). Physico chemical properties of whey protein \& gelatine biopolymer using tea leaf extract as crosslink materials. Current Research in Nutrition \& Food Science Journal, 3 (3), 224-236.

Tamime, A. Y., Robinson, R. K. (Richard K., \& Tamime, A. Y. (2007). Tamime \& Robinson's yogurt: science \& technology. New York: CRC.

Spilimbergo, S. (2011). Milk pasteurization at low temperature under $\mathrm{N}_{2} \mathrm{O}$ pressure. Journal of Food Engineering, 105(1), 193-195.

https://doi.org/10.1016/J.Jfoodeng.2011.02.006 